\title{
Climate change impacts on yield and financial performance of agro-plantation companies in Malaysia
}

\section{Md. Mahmudul Alam*, Yusnidah Ibrahim and Md. Shahin Mia}

\author{
School of Economics, Finance and Banking, \\ Universiti Utara Malaysia, Malaysia \\ Email: rony000@gmail.com \\ Email: yibrahim@uum.edu.my \\ Email: shahin@uum.edu.my \\ *Corresponding author
}

\begin{abstract}
In Malaysia, there is a declining trend in agricultural productivity and crop yields due to various climate events in the recent years. Therefore, this study aims to examine the impacts of climate change, especially El Nino and flood, on the financial performance of Malaysian agro and plantation firms. The study used a panel dataset on 33 Malaysian agro and plantation firms listed in Bursa Malaysia for the period of 2003 to 2016. A panel of regression models including GMM, pooled OLS, random effect and fixed effect were used to analyse the data. The results show that both the El Nino and flood have significant negative impact on the firms' financial performance as measured by ROA and ROE. The findings indicate that climate change results in reduction of agricultural production which reduces revenue and consequently the profit of the agro and plantation firms. The study findings might help the firm managers as well as policy makers to take into consideration the environmental factors that affect the overall financial health of the firms and take appropriate adaptation and mitigation policies to climate change at firm level and macro level in the country.
\end{abstract}

Keywords: climate change; El Nino; flood; agro firm; plantation firm; financial performance; return on assets; ROA; return on equity; ROE; panel regression; Malaysia.

Reference to this paper should be made as follows: Alam, M.M., Ibrahim, Y. and Mia, M.S. (2020) 'Climate change impacts on yield and financial performance of agro-plantation companies in Malaysia', Int. J. Postharvest Technology and Innovation, Vol. 7, No. 1, pp.15-28.

Biographical notes: Md. Mahmudul Alam is a Senior Lecturer of Finance at the Universiti Utara Malaysia, and a fellow at the Frankfurt School of Finance and Management, University Technology MARA, and International Islamic University Chittagong. $\mathrm{He}$ obtained his $\mathrm{PhD}$ and Master's in Environment and Development (Finance and Economics) from the National University of Malaysia. He has more than 100 articles in refereed journals and five books/monographs. He has presented more than 80 articles at international conferences. He is recognised by BDRC as one of the 'Top Bangladesh Development Researchers of the Millennium'. His research areas include sustainable finance, sustainable business, sustainable development, Islamic finance and financial economics. 
Yusnidah Ibrahim is a Professor of Finance and the Deputy Vice Chancellor in Academic and International at the University Utara Malaysia. She obtained her BA and MSc in Actuarial Science from the University of Iowa in USA, and $\mathrm{PhD}$ from the De Montfort University in UK. In terms of professional involvement, she possesses the Registered Financial Planner (RFP) designation and Certificate in Risk Management (CFM). She also serves as the editorial board member of the International Journal of Banking and Finance (IJBF) and International Journal of Management Studies (IJMS). She has undertaken consultation work on Private Financial Initiative (PFI) models, small business financial planning, and higher education funding. Her research and publications are in the areas of capital structure, dividend policy, Islamic bonds (Sukuk), small business finance, and higher education finance. Her research and publications are in the areas of capital structure, dividend policy, Islamic bonds (Sukuk), small business finance, and higher education finance.

Md. Shahin Mia is currently affiliated with the Department of Finance at the Universiti Utara Malaysia as a Senior Lecturer. Previously he was affiliated with the Department of Finance and Banking at the Hajee Mohammad Danesh Science and Technology University (HSTU) in Bangladesh as an Assistant Professor. He obtained his PhD in Economics (Environment and Development) from the Universiti Kebangsaan Malaysia (UKM). He also holds a BBS (hons.) and MBA in Finance and Banking from the Rajshahi University, Bangladesh. His research works have been published in a wide range of international and local journals. He has presented many articles at international conferences.

\section{Introduction}

The performance of a firm might be affected by different factors. Climate change could be among the factors inhibiting productivity of the firms especially in agricultural sector. Climate is the statistics of weather of a country over the long period measured by the amount of precipitation, temperature, relative humidity, flood and drought (Alam et al., 2017). The climate has been changing over time with a rapid change recorded in the recent years. For example, the world annual average temperature of $0.70^{\circ} \mathrm{C}$ is more than what was recorded in both the 20th and 19th centuries (Karla, 2007). The recent climate change such as flood and drought destructed the crops and reduced agriculture production (Ibrahim and Alam, 2016). Needless to say, however, a perfect temperature and rainfall enhance the growth of crops which increases their yield.

In spite of the significant contribution of the agriculture sector to the economic growth of many countries, it is affected by climate change damaging several crops and causing a decline in the farm produce. Evidently, the flash floods or hurricanes disrupt the agricultural activities. In addition, the drought caused by El Nino is a major threat to crops yield. Although, El Nino Southern Oscillation (ENSO) is a climate event that originates in the Pacific Ocean, it affects the global weather through droughts and floods (Kovats et al., 2003). The previous studies revealed that the El Nino is a recurrent weather phenomenon that takes place approximately every two to eight years and remains for 12 to 18 months (Kovats et al., 2003; Moy et al., 2002). Moreover, a number of studies had been conducted to assess the impacts of climate change on agricultural production (Aydinalp and Cresser, 2008; Bosello and Zhang, 2005; Collier, 2007; Rosenzweig et al., 2002). The findings of these studies revealed that climate change has 
negative impacts on the agricultural production and crop yield. The decline in crop production could be one of the reasons of the declining firm's profitability.

Agriculture sector plays a significant role in Malaysian economy. On average, $10 \%$ of the country's total GDP comes from the agricultural production. Moreover, Malaysia is a leading exporter of palm oil and rubber around the world. However, in the recent years, there is a declining trend in agricultural productivity and crop yields due to various climate events such as flood, drought, El Nino and so on. In Malaysia, the increasing seasonal temperature related to El Nino from 2015-2016 caused a sharp decline in agricultural production (Kamil and Omar, 2016). It was reported that production in agricultural sector reduced from RM94.14 billion in 2015 to RM93.58 billion in 2016 (UNDP, 2017). Decrease in agricultural production due to climate change might be one of the possible reasons of declining profitability and performance of the agricultural firms in the country. However, the direct impacts of climate change on financial performance of agricultural firms are not clearly known. To the researchers' knowledge, no study has been conducted yet to assess the relationship between climate change and agricultural firms' performance in the Malaysian scenario. Therefore, this study aims to fulfil the research gap by assessing the impacts of climate change on financial performance of agro and plantation companies in Malaysia. The study is the first academic attempt to identify the climatic factors that affect the financial performance of agro and plantation firms in Malaysia.

\section{Literature review}

\subsection{El Nino and firm performance}

ENSO is a climate event that originates in the Pacific Ocean and impacts global weather. El Nino phenomenon is the most potential source of climatic variability (Berry and Okulicz-Kozaryn, 2008). It causes frequent droughts and floods (Kovats et al., 2003). El Nino could be a reason of less productivity in agro-based firms in a country. The study by Cashin et al. (2017) found that El Nino has negative impact on real economic activity in South Africa, Philippines, Peru, Indonesia, Brazil, and Australia. On the other hand, it has positive impact on real economic activity in USA, Thailand, Singapore, Europe, Chile, China, Canada, and Argentina. Therefore, this study considers the following hypothesis:

H1 There is statistically significant relationship between El Nino and firm's financial performance (ROA and ROE).

\subsection{Flood and firm performance}

Flash flood can occur suddenly and cause hazards such as landslides, damage to infrastructure, mud flows and even death (Collier, 2007). These hazards impact directly to the agricultural production and quality of the product and subsequently affects firm's performance. For example, the flood in the Yangtze basin adversely affected crops production and damaged land and houses; consequently, China faced huge economical losses (Piao, 2010). In Thailand, the 2011 flood affected 69 provinces of the country, and damaged 16,668.55 square $\mathrm{km}$ of agricultural area and 9,859 factories (Ministry of 
Agriculture and Cooperatives, 2012). Total damage and loss were estimated to be $\$ 1,318 \mathrm{~m}$ in agriculture, livestock and fishery sectors (Poaponsakorn and Meethom, 2013). The study also reported that the 2011 flooding had a large negative impact on the farm profits of some middle-income households in the flooded provinces. In Bangladesh, the average loss in the national paddy crop was estimated to be nearly $6.4 \%$ per year due to floods, typhoons and droughts (FAO, 2011). Therefore, this study develops the following hypothesis:

H2 There is statistically significant relationship between flood and firm's financial performance (ROA and ROE).

\subsection{Leverage and firm performance}

A good number of studies have been conducted to assess the relationship between leverage and firm's financial performance. Some studies found positive relationship between leverage and firm's financial performance while others revealed negative relationship between them. However, some other studies reported that leverage does not affect firm's performance. In other words, there is no impact of leverage on the financial performance of a firm.

Clifford and Lindsey (2016) conducted study on S\&P 1500 firms from 1996 to 2005. They found a positive and significant relationship between leverage and ROA. Similar findings were obtained by other studies (Davydov, 2016; Roy, 2016). The study by Kwong (2016) employed a sample of 680 Malaysian non-financial firms for the period of 2003-2012 and found positive and significant relationship between leverage and ROE. It indicates that firms with higher leverage can generate more profit. This finding is supported by a number of studies around the world (Garcia-Castro et al., 2010; Azeez, 2015; Elyasiani and Zhang, 2015).

Burca and Batrinca (2014) conducted a study on 105 insurance companies in Romania using panel data from 2008 to 2012. They found that leverage is negatively associated with ROA. The negative result indicates that usage of leverage (i.e., financing firm's activities through debt capital) rather than issuing equity capital results in increased browning and magnifies the bankruptcy risk in the event of unexpected losses which causes reduction in firm's performance. Some other studies also found negative influence of leverage on ROA (Anderson and Reeb, 2003; Nguyen and Nguyen, 2015; Chang and Boontham, 2017; Lim et al., 2017). On the other hand, a study on the firms listed in Indian Stock Exchange found significant negative relationship between leverage and ROE (Roy, 2016). Negative relationship between leverage and ROE suggests that increase in leverage tends to decrease firm's profitability and vice versa. Similar results were reported by a number of studies around the world (Sami et al., 2011; Mirza and Javed, 2013; Yu, 2013; Liu et al., 2015; Nguyen and Nguyen, 2015; Siddik et al., 2017; Atan et al., 2018).

However, another study on all listed firms in India found that leverage is not a significant determinant of firm's financial performance measured by ROA (Chaudhuri et al., 2016). Some other studies also found that there is no significant linkage between leverage and ROA (Heffernan and Fu, 2010; Ekholm and Maury, 2014; Muhamed et al., 2014). Similar with this line, a number of studies revealed that there is no impact of leverage on the firm's financial performance measured by ROE (Heffernan and Fu, 2010; 
Ahmad et al., 2012; Muhamed et al., 2014; Zouari and Taktak, 2014). Based on the above discussion, this study considers the following hypothesis:

H3 There is statistically significant relationship between leverage and firm's financial performance (ROA and ROE).

\subsection{Firm size and firm performance}

Firm size is an important determinant of firm's profitability. Generally, large firms are more diversified, more able to utilise advance technology and well overseen. Therefore, it is hoped that the firm size can affect a firm positively and probably boost firm performance (Margaritis and Psillaki, 2010). However, previous studies reported mix findings about the relationship between firm size and firm performance.

Lewandowski (2017) conducted a study consisting of 1,640 companies over the period of 2003-2015. The study discovered a positive and significant impact of firm size on ROA of the companies. Some other studies also found a positive and significant effect of firm size on ROA because big firms are well risk diversified, better in expenses management, and have complex information system (Hanifa and Hudaib, 2006; Burca and Batrinca, 2014; Nguyen and Nguyen, 2015; Nimtrakoon, 2015; Daher and Le Saout, 2015; Clifford and Lindsey, 2016; Lim et al., 2017). Similar with this line, Siddik et al. (2017) examined the linkage between capital structure and performance of 22 Bangladeshi banks over a nine-year period (2005-2014) and found a positive relationship between firm size and ROE. Almost similar findings were observed by a number of previous studies (Garcia-Castro et al., 2010; Mirza and Javed, 2013; Liu et al., 2015; Nguyen and Nguyen, 2015).

On the other hand, several studies found negative impact of firm size on ROA (Hoque et al., 2013; Liang et al., 2013; Rachdi, 2013; Weng and Chen, 2017; Upadhyay et al., 2017). Similarly, a few researchers also found that firm size negatively influences ROE of the firms (Liang et al., 2013; Rachdi, 2013; Elyasiani and Zhang, 2015; Kwong, 2016; Roy, 2016). However, a few studies found no significant impact of firm size on financial performance measured by either ROA or ROE (Besser, 1999; Gong et al., 2008; Garcia-Castro et al., 2010; Hoque et al., 2013; Ekholm and Maury, 2014; Muhamed et al., 2014; Azeez, 2015). Based on the above discussion, this study considers the following hypothesis:

H4 There is statistically significant relationship between firm size and firm's financial performance (ROA and ROE).

\subsection{Liquidity and firm performance}

Liquidity is defined as the firm's ability to fulfil its short-term obligations. Liquidity is considered as availability of internal fund and an important factor of investment (Hoshi et al., 1991). Moreover, liquidity management is concerned itself with the allocation of how much wealth should be in hand and how much should be invested in alternative financial assets (Tobin, 1958). Thus, firm's liquidity level might be an important determinant of firm performance.

During the past few decades, numerous studies have been carried out to assess the impact of liquidity on the firm's financial performance. The study by Rachdi (2013) 
employed a sample of large number of Tunisian commercial banks over the period of 2000-2010 and revealed significant and positive relationship between liquidity and firm financial performance as measured by ROA. In Bangladesh, Rahman et al. (2015) investigated the determinants of bank profitability and revealed the similar findings. In line with these studies, Heffernan and $\mathrm{Fu}$ (2010) found that liquidity is significantly and positively related with ROE in the banking sector of china. Almost similar findings were observed by other studies (Rachdi, 2013; Rahman et al., 2015). The findings of these studies indicate that firms with high level of liquidity generate more profit.

On the other hand, Davydov (2016) examined the effect of public and bank debt financing on firm's financial performance. The researcher found a negatively association of liquidity with firm's ROA. Adams and Buckle (2003) also found a significant and negative relationship between liquidity and ROA. In line with these studies, Mirza and Javed (2013) and Gurbuz et al. (2010) identified that liquidity negatively and significantly affects firm's ROE. They argued that high liquidity means firm holding too much cash on hand that could make more profit if it was invested properly.

However, a number of researchers reported that liquidity does not significantly influence firm's financial performance measured by either ROA or ROE (Heffernan and Fu, 2010; Hoque et al., 2013; Liang et al., 2013; Ongore and Kusa, 2013; Muhamed et al., 2014; Siddik et al., 2017). Therefore, this study considers the following hypothesis:

H5 There is statistically significant relationship between liquidity and firm's financial performance (ROA and ROE).

\section{Materials and methods}

\subsection{Data collection}

We conducted a retrospective secondary-data-based study and used the annual data on agro and plantation firms in Malaysia for the period of 2003 to 2016. All the agro and plantation related firms in Malaysia are listed under the plantation sector in Bursa Malaysia. During the study period, a total of 43 companies were registered under the plantation sector. However, due to unavailability of long time series data of newly registered companies, this study took into consideration only 33 companies for the collection of data between 2003 and 2016. A panel dataset of 462 firm-year observations (i.e., 33 plantation firms $\times 14$ years data) were collected from DataStream and Bursa Malaysia. Data for the climatic events (i.e., El Nino and flood) were extracted from various sources such as Climate Prediction Center of USA, World Bank, Department of Statistics, Malaysia and Newspapers.

\subsection{Measurement of variables}

Measurement of the various variables used in this study is discussed in the following sub-sections.

\subsubsection{Financial performance variables}

This study used accounting-based measurements, mainly return on assets (ROA) and return on equity (ROE) to quantify the financial performance of the study firms. ROA 
and ROE have been widely used in the previous literatures to measure firm's financial performance (Burca and Batrinca, 2014; Ekholm and Maury, 2014; Chang and Boontham, 2017). ROA measures the overall effectiveness of a firm in generating profits with its available assets (Nimtrakoon, 2015). On the other hand, ROE measures the return earned on common stockholders' investment (i.e., equity capital) in the firm (Muhamed et al., 2014).

ROA can be calculated as follows (Davydov, 2016; Frijns et al., 2016; Nimtrakoon, 2015):

$$
R O A=\text { Net income } \div \text { Book value of the total assets }
$$

ROE can be calculated as follows (Anderson and Reeb, 2003; Liu et al., 2015):

$$
R O E=\text { Net income } \div \text { Book value of the total equity }
$$

\subsubsection{Climate variables}

This study used El Nino and flood to quantify the climate change. ENSO is a climate event originated in equatorial zone of the Pacific Ocean which affects the atmospheric circulation worldwide and is associated with droughts and floods (Kiladis and Diaz, 1989; Kovats et al., 2003). On the other hand, flood is a natural disaster which can cause extensive damages in a country, particularly the agricultural production. The flash flood occurs suddenly and causes hazards such as landslides, damages to infrastructure, mud flows and even death (Collier, 2007). For this study, El Nino and flood have been considered as dummy variables, where 1 indicates that the event happens in a particular year and 0 otherwise.

\subsubsection{Control variables}

This study also considered few control variables such as financial leverage, firm size and liquidity in the regression models. The leverage ratio is a measure of optimal capital structure of a firm based on total debt by total assets (Sami et al., 2011; Chi and Su, 2017). This study used total assets as a proxy of the firm size (Adams et al., 2005; Burca and Batrinca, 2014). Liquidity refers to how quickly a firm's asset or security can be converted into cash without losing real value of the asset. One of the basic measures of a firm's liquidity is current ratio which is calculated as current assets by current liabilities (Davydov, 2016; Rachdi, 2013; Muhamed et al., 2014).

\subsection{Econometric model}

Initially, this study employed the pooled OLS (POLS), fixed effect (FE) and random effect (RE) models to test hypotheses of the study. However, all of these methods have some limitations. The POLS enacts that intercept and slop coefficient of all cross-sections are same and denies the heterogeneity that may exist among the entities (Bollen and Brand, 2010). The FE model assumes that the individual effect of $\alpha_{i}$ is correlated with the predictor variable $X_{i t}$ while the RE model assumes no correlation. Hence, the error term in RE becomes $\left(\mu_{i}+\varepsilon_{i t}\right)$, whereby $\mu_{i}$ is the specific RE element for the group which is similar to $\varepsilon_{i t}$ except that with $\mu_{i}$, for every group there is a single draw that is considered in the regression identically for each time (Wooldridge, 2006; Gujarati and Porter, 2010). 
Furthermore, due to the limitations of the panel static models of POLS, FE and RE, this study used the system generalised method of moments (GMM) model developed by Arellano and Bond (1991) to address the potential endogeneity problem commonly found in the dynamic panel models. The panel datasets normally exhibit the characteristics of both heteroskedasticity and autocorrelation. Thus, application of suitable instruments for the regressors can be a way out to the problem. Hence the system GMM model employed for estimation in this study is capable of overcoming the limitations of the panel static models as well as handling both the endogeneity and serial correlation problem found in most of the panel models including the FE and pooled OLS models.

The operational models of this study is:

$$
\begin{aligned}
& R O A_{i t}=\alpha_{0}+\alpha_{1} E L N_{i t}+\alpha_{2} F L D_{i t}+\alpha_{3} L I Q D_{i t}+\alpha_{4} F S Z_{i t}+\alpha_{5} F L V_{i t}+\varepsilon_{i t} \\
& R O E_{i t}=\alpha_{0}+\alpha_{1} E L N_{i t}+\alpha_{2} F L D_{i t}+\alpha_{3} L I Q D_{i t}+\alpha_{4} F S Z_{i t}+\alpha_{5} F L V_{i t}+\varepsilon_{i t}
\end{aligned}
$$

where

$\begin{array}{ll}R O A & \text { return on assets } \\ R O E & \text { return on equity } \\ E L N & \text { El Nino } \\ F L D & \text { flood } \\ L I Q D & \text { liquidity } \\ F S Z & \text { firm size } \\ F L V & \text { financial leverage } \\ \beta & \text { coefficient to be estimated } \\ \varepsilon & \text { error term } \\ i & 1,2,3, \ldots n, \text { are companies } \\ t & 1,2,3, \ldots, t, \text { are time periods. }\end{array}$

Moreover, to find the best fit model from POLS, FE and RE, this study relies on Haussmann specification test. In case of GMM, the system GMM combines a set of equations in the first difference with suitable lags as instruments. Therefore, the validity of the instruments used can be evaluated using the Sargan test of over-identifying restrictions while the Arellano-Bond test of $\mathrm{AR}(2)$ displays the presence/absence of the second order autocorrelation in the model.

\section{Result and discussion}

\subsection{Correlation analysis}

The correlation matrix shows that only firm size is positively correlated with ROA and ROE (Table 1). However, leverage, liquidity, El Nino and flood are negatively correlated with ROA and ROE. 
Table 1 Correlations matrix

\begin{tabular}{|c|c|c|c|c|c|c|c|}
\hline & $R O A$ & $R O E$ & $L E V$ & $F S Z$ & $L I Q D$ & $E L N$ & $F L D$ \\
\hline \multirow[t]{2}{*}{ ROA } & 1.0000 & 0.6985 & -0.1821 & 0.3499 & -0.1377 & -0.0546 & -0.0318 \\
\hline & & $(0.0000)$ & $(0.0001)$ & $(0.0000)$ & $(0.0030)$ & $(0.2414)$ & $(0.4959)$ \\
\hline \multirow[t]{2}{*}{ ROE } & & 1.0000 & -0.0563 & 0.2970 & -0.0820 & -0.0228 & -0.0238 \\
\hline & & & $(0.2269)$ & $(0.0000)$ & $(0.0785)$ & $(0.6246)$ & $(0.6095)$ \\
\hline \multirow[t]{2}{*}{ LEV } & & & 1.0000 & 0.0610 & -0.4028 & -0.0331 & -0.0140 \\
\hline & & & & $(0.1908)$ & $(0.0000)$ & $(0.4778)$ & $(0.7639)$ \\
\hline \multirow[t]{3}{*}{ FSZ } & & & & 1.0000 & -0.2046 & 0.1548 & 0.0590 \\
\hline & & & & & $(0.0000)$ & $(0.0008)$ & $(0.2059)$ \\
\hline & & & & & $(0.0000)$ & $(0.0243)$ & $(0.3609)$ \\
\hline \multirow[t]{3}{*}{ LIQD } & & & & & 1.0000 & 0.0095 & -0.0076 \\
\hline & & & & & & $(0.8382)$ & $(0.8710)$ \\
\hline & & & & & & $(0.0000)$ & $(0.0000)$ \\
\hline \multirow[t]{2}{*}{ ELN } & & & & & & 1.0000 & 0.1886 \\
\hline & & & & & & & $(0.0000)$ \\
\hline FLD & & & & & & & 1.0000 \\
\hline
\end{tabular}

Note: *P-values are in parenthesis.

\subsection{Regression analysis}

Among the diagnostic test to determine the best fit model, the post estimation results of the system GMM explain the Sargan test of over-identifying restrictions and the test of second order serial correlation (Table 2). As presented, the probability values of the Sargan tests imply that the null hypothesis of valid instruments cannot be rejected. Similarly, the AR(2) probability values show the absence of second order serial correlation of the error term suggesting the system GMM would be a consistent model. Moreover, based on the Haussmann test, FE model was found the appropriate model out of POLS, FE and RE. Therefore, this analysis only reported the output of FE and the system GMM.

Table 2 shows that El Nino has a negative and statistically significant impact on the ROA and ROE based on GMM model, but no significant effect under FE model. The findings suggest that climate change affects negatively the firms' profitability as measured by ROA and ROE. The finding of the present study is in line with the results of Cashin et al. (2017) where El Nino was identified as an important cause of decrease in the farm produce. Similarly, the flood has highly negative and significant impacts on both ROA and ROE under the GMM and FE model. Piao (2010) also revealed the similar finding. It indicates that irrespective of the indicators of firm performance (i.e., ROA or ROE), flood causes an adverse effect on farm produce. Therefore, overall it can be inferred that climate change results in reduction of agricultural production which reduces revenue and consequently the profit of the agro and plantation firms. 
Table 2 Regression output

\begin{tabular}{lccccc}
\hline \multirow{2}{*}{ Variable } & \multicolumn{2}{c}{ ROA } & & \multicolumn{2}{c}{ ROE } \\
\cline { 2 - 3 } \cline { 5 - 6 } ELN & Fixed effect & GMM & & Fixed effect & GMM \\
\cline { 3 - 5 } FLD & -4.02 & $-31.632^{* * *}$ & & -5.07 & $-11.69^{* *}$ \\
& $(10.66)$ & $(2.04)$ & & $(11.61)$ & $(6.61)$ \\
LIQD & $-33.75^{* *}$ & $-20.62^{* * *}$ & & $-28.36^{* *}$ & $-17.70^{* *}$ \\
& $(10.07)$ & $(1.17)$ & & $(10.87)$ & $(6.16)$ \\
FSZ & -0.028 & $-0.186^{* * *}$ & & -0.076 & $-0.28^{* * *}$ \\
& $(0.34)$ & $(0.045)$ & & $(0.37)$ & $(0.06)$ \\
FLV & 0.010 & $0.055^{* * *}$ & & 0.069 & $0.16^{* * *}$ \\
& $(0.07)$ & $(0.011)$ & & $(0.085)$ & $(0.03)$ \\
Sargan test prob. & $-0.109^{* *}$ & $-0.599^{* * *}$ & & $-0.023^{*}$ & $-0.516^{* *}$ \\
AR(2) prob. & $(0.04)$ & $(0.011)$ & & $(0.047)$ & $(0.03)$ \\
\hline
\end{tabular}

Notes: The values in parentheses are standard errors and the notation $* * *, * *$ and $*$ denote significance level at $1 \%, 5 \%$ and $10 \%$ respectively.

The study revealed that firms' characteristics also have impact on the performance of the agro and plantation firms in Malaysia (Table 2). It was found that the relationship between liquidity and the indicators of firm performance (i.e., ROA and ROE) is negative and statistically significant under the GMM model while it is negative but not statistically significant under the FE model. It indicates that holding high volume of liquidity reduces the return of the firm. The negative impact of liquidity on firm performance goes in line with the findings of Davydov (2016) and Mirza and Javed (2013). However, the study revealed positive impacts of firm size on firm performance using the GMM model. A number of previous studies also found positive relationship between firm size on firm performance (Abiodun, 2013; Doğan, 2013; Sritharan, 2018). In addition, the impact of financial leverage on ROA and ROE were found to be negative and statistically significant under the GMM and FE model. The negative impact of financial leverage on the firm performance was also reported in the study by Clifford and Lindsey (2016). The findings indicate that the firms that are highly leveraged have lower chance to earn sufficient return to meet their financial obligations.

\section{Conclusions}

The present study aims to examine the impacts of climate change on the financial performance of Malaysian agro and plantation firms. The results show that the climate change variables (i.e., El Nino and flood) have a significant impact on firm's financial performance measured by ROA and ROE. The negative impacts of flood and El Nino imply that climate change has an adverse effect on agricultural production and subsequently on revenue and profitability of the firms. The study also revealed a significant relationship between firm's characteristics (such as financial leverage, firm 
size and liquidity) and firm's profitability (i.e., ROA and ROE). Therefore, it can be concluded that both the climate change and firm's characteristics affect significantly the financial performance of the agro and plantation firms in Malaysia.

To our knowledge, no study has been conducted yet to assess the impacts of climate change on financial performance of Malaysian agro and plantation firms. Therefore, the present study might be considered an important contribution to the existing literature. Moreover, the findings of the study would be beneficial to the top-level management of the agro and plantation firms to identify the factors that affect the financial performance of their firms. Therefore, the managers can be cautious about the environmental factors that might affect the overall financial health of the firms and can take proper decision and apply corrective measures to enhance the firm's profitability.

Despite a significant contribution to the existing literature, this study has several limitations which create the scope for future research. Firstly, the study was limited to 33 Malaysian agro and plantation firms listed in Bursa Malaysia due to unavailability of data of a number of public listed plantation firms in the country. Therefore, further research can be conducted by including the private plantation firms which might increase the number of observations as well as acceptability of findings. Secondly, the study is confined to only the Malaysian agro and plantation firms. Thus, future research can be carried out in other countries of the South-East Asian region which might broaden the scope of the study as well as generalise the study findings. Finally, future research can be carried out to include other climatic factors to find out other possible determinants of performance of agro and plantation firms in the country.

\section{Acknowledgements}

We are very thankful to Universiti Utara Malaysia (UUM) for supporting this research from the project code: UUMSO\#13715.

\section{References}

Abiodun, B.Y. (2013) 'The effect of firm size on firms profitability in Nigeria', Journal of Economics and Sustainable Development, Vol. 4, No. 5, pp.90-94.

Adams, M. and Buckle, M. (2003) 'The determinants of corporate financial performance in the Bermuda insurance market', Applied Financial Economics, Vol. 13, No. 2, pp.133-143.

Adams, R.B., Almeida, H. and Ferreira, D. (2005) 'Powerful CEOs and their impact on corporate performance', Review of Financial Studies, Vol. 18, No. 4, pp.1403-1432.

Ahmad, Z., Abdullah, N.M. and Roslan, S. (2012) 'Capital structure effect on firms performance: focusing on consumers and industrials sectors on Malaysian firms', International Review of Business Research Papers, Vol. 8, No. 5, pp.137-155.

Alam, M.M., Taufique, K.M. and Sayal, A. (2017) 'Do climate changes lead to income inequality? Empirical study on the farming community in Malaysia', International Journal of Environment and Sustainable Development, Vol. 16, No. 1, pp.43-59.

Anderson, R.C. and Reeb, D.M. (2003) 'Founding-family ownership and firm performance: evidence from the S\&P 500', The Journal of Finance, Vol. 58, No. 3, pp.1301-1328.

Arellano, M. and Bond, S. (1991) 'Some tests of specification for panel data: Monte Carlo evidence and an application to employment equations', The Review of Economic Studies, Vol. 58, No. 2, pp.277-297. 
Atan, R., Alam, M.M., Said, J. and Zamri, M. (2018) 'The impacts of environmental, social, and governance factors on firm performance: panel study of Malaysian companies', Management of Environmental Quality, Vol. 29, No. 2, pp.182-194.

Aydinalp, C. and Cresser, M.S. (2008) 'The effects of global climate change on agriculture', American-Eurasian Journal of Agricultural \& Environmental Sciences, Vol. 3, No. 5, pp.672-676.

Azeez, D.A. (2015) 'Corporate governance and firm performance: evidence from Sri Lanka', Journal of Finance and Bank Management, Vol. 3, No. 1, pp.180-189.

Berry, B.J. and Okulicz-Kozaryn, A. (2008) 'Are there ENSO signals in the macroeconomy?', Ecological Economics, Vol. 64, No. 3, pp.625-633.

Besser, T.L. (1999) 'Community involvement and the perception of success among small business operators in small towns', Journal of Small Business Management, Vol. 37, No. 4, pp.16-29.

Bollen, K.A. and Brand, J.E. (2010) 'A general panel model with random and fixed effects: a structural equations approach', Social Forces, Vol. 89, No. 1, pp.1-34.

Bosello, F. and Zhang, J. (2005) 'Assessing climate change impacts: agriculture', SSRN Electronic Journal, DOI: $10.2139 / \mathrm{ssrn} .771245$.

Burca, A. and Batrinca, G. (2014) 'The determinants of financial performance in the Romanian insurance market', International Journal of Academic Research in Accounting, Finance and Management Sciences, Vol. 4, No. 1, pp.299-308.

Cashin, P., Mohaddes, K. and Raissi, M. (2017) 'Fair weather or foul? The macroeconomic effects of El Niño', Journal of International Economics, Vol. 106, pp.37-54.

Chang, S. and Boontham, W. (2017) 'Post-privatization speed of state ownership relinquishment: determinants and influence on firm performance', The North American Journal of Economics and Finance, Vol. 41, pp.82-96.

Chaudhuri, K., Kumbhakar, S.C. and Sundaram, L. (2016) 'Estimation of firm performance from a MIMIC model', European Journal of Operational Research, Vol. 255, No. 1, pp.298-307.

Chi, J.D. and Su, X. (2017) 'The dynamics of performance volatility and firm valuation', Journal of Financial and Quantitative Analysis, Vol. 52, No. 1, pp.111-142.

Clifford, C.P. and Lindsey, L. (2016) 'Blockholder heterogeneity, CEO compensation, and firm performance', Journal of Financial and Quantitative Analysis, Vol. 51, No. 5, pp.1491-1520.

Collier, C.G. (2007) 'Flash flood forecasting: what are the limits of predictability?', Quarterly Journal of the Royal Meteorological Society, Vol. 133, No. 622, pp.3-23.

Daher, L. and Le Saout, E. (2015) 'The determinants of the financial performance of microfinance institutions: impact of the global financial crisis', Strategic Change, Vol. 24, No. 2, pp.131-148.

Davydov, D. (2016) 'Debt structure and corporate performance in emerging markets', Research in International Business and Finance, Vol. 38, pp.299-311.

Doğan, M. (2013) 'Does firm size affect the firm profitability? Evidence from Turkey', Research Journal of Finance and Accounting, Vol. 4, No. 4, pp.53-59.

Ekholm, A. and Maury, B. (2014) 'Portfolio concentration and firm performance', Journal of Financial and Quantitative Analysis, Vol. 49, No. 4, pp.903-931.

Elyasiani, E. and Zhang, L. (2015) 'Bank holding company performance, risk, and 'busy' board of directors', Journal of Banking \& Finance, Vol. 60, pp.239-251.

FAO (2011) Agricultural Insurance in Asia and the Pacific Region, pp.1-225, Food and Agriculture Organization of the United Nations Regional Office for Asia and the Pacific; Bangkok, Thailand.

Frijns, B., Dodd, O. and Cimerova, H. (2016) 'The impact of cultural diversity in corporate boards on firm performance', Journal of Corporate Finance, Vol. 41, pp.521-541.

Garcia-Castro, R., Ariño, M. A., \& Canela, M.A. (2010) 'Does social performance really lead to financial performance? Accounting for endogeneity', Journal of Business Ethics, Vol. 92, No. 1, pp.107-126. 
Gong, G., Louis, H. and Sun, A.X. (2008) 'Earnings management and firm performance following open-market repurchases', The Journal of Finance, Vol. 63, No. 2, pp.947-986.

Gujarati, D.N. and Porter, D.C. (2010) Essentials of Econometrics, 4th ed., McGraw-Hill, New York.

Gurbuz, A.O., Aybars, A. and Kutlu, O. (2010) 'Corporate governance and financial performance with a perspective on institutional ownership: empirical evidence from Turkey', Journal of Applied Management Accounting Research, Vol. 8, No. 2, pp.21-37.

Hanifa, R. and Hudaib, M. (2006) 'Corporate governance structure and performance of Malaysian listed companies', Journal of Business Finance \& Accounting, Vol. 33, No. 7, pp.1034-1062.

Heffernan, S.A. and Fu, X. (2010) 'Determinants of financial performance in Chinese banking', Applied Financial Economics, Vol. 20, No. 20, pp.1585-1600.

Hoque, M.Z., Islam, M.R. and Azam, M.N. (2013) 'Board committee meetings and firm financial performance: an investigation of Australian companies', International Review of Finance, Vol. 13, No. 4, pp.503-528.

Hoshi, T., Kashyap, A. and Scharfstein, D. (1991) 'Corporate structure, liquidity, and investment: evidence from Japanese industrial groups', The Quarterly Journal of Economics, Vol. 106, No. 1, pp.33-60.

Ibrahim, A.Z. and Alam, M.M. (2016) 'Climatic changes, government interventions, and paddy production: an empirical study of the Muda irrigation area in Malaysia', International Journal of Agricultural Resources, Governance and Ecology, Vol. 12, No. 3, p.292.

Kamil, N.N. and Omar, S.F. (2016) 'Climate variability and its impact on the palm oil industry', Oil Palm Industry Economic Journal, Vol. 16, No. 1, pp.18-30.

Karla, N., Chander, S., Pathak, H., Aggarwal, P.K., Gupta, N.C., Sehgal, M. and Chakraborty, D. (2007) 'Impacts of climate change on agriculture', Outlook on Agriculture, Vol. 36, No. 2, pp.109-118.

Kiladis, G.N. and Diaz, H.F. (1989) 'Global climatic anomalies associated with extremes of the Southern Oscillation', Journal of Climate, Vol. 2, pp.1069-1090.

Kovats, R.S., Bouma, M.J., Hajat, S., Worrall, E. and Haines, A. (2003) 'El Niño and health', The Lancet, Vol. 362, pp.1481-1489.

Kwong, L.C. (2016) 'How corporate derivatives use impact firm performance?', Pacific-Basin Finance Journal, Vol. 40, Part A, pp.102-114.

Lewandowski, S. (2017) 'Corporate carbon and financial performance: the role of emission reductions', Business Strategy and the Environment, Vol. 26, No. 8, pp.1196-1211.

Liang, H., Ching, Y.P. and Chan, K.C. (2013) 'Enhancing bank performance through branches or representative offices? Evidence from European banks', International Business Review, Vol. 22, No. 3, pp.495-508.

Lim, C.Y., Wang, J. and Zeng, C. (2017) China's 'mercantilist' government subsidies, the cost of debt and firm performance', Journal of Banking \& Finance, Vol. 86, pp.37-52.

Liu, Y., Miletkov, M.K., Wei, Z. and Yang, T. (2015) 'Board independence and firm performance in China', Journal of Corporate Finance, Vol. 30, pp.223-244.

Margaritis, D. and Psillaki, M. (2010) 'Capital structure, equity ownership and firm performance', Journal of Banking \& Finance, Vol. 34, No. 3, pp.621-632.

Ministry of Agriculture and Cooperatives (MOAC) (2012) Report on Impact of Flood on Farmers, May-December, MOAC, Bangkok, Thailand.

Mirza, S.A. and Javed, A. (2013) 'Determinants of financial performance of a firm: case of Pakistani stock market', Journal of Economics and International Finance, Vol. 5, No. 2, pp.43-52.

Moy, C.M., Seltzer, G.O., Rodbell, D.T. and Anderson, D.M. (2002) 'Variability of El Niño/southern oscillation activity at millennial timescales during the Holocene epoch', Nature, Vol. 420, No. 6912, pp.162-165. 
Muhamed, A.B., Stratling, R. and Salama, A. (2014) 'The impact of government investment organizations in Malaysia on the performance of their portfolio companies', Annals of Public and Cooperative Economics, Vol. 85, No. 3, pp.453-473.

Nguyen, T. and Nguyen, H. (2015) 'Capital structure and firms' performance: evidence from Vietnam's stock exchange', International Journal of Economics and Finance, Vol. 7, No. 12, p.1.

Nimtrakoon, S. (2015) 'The relationship between intellectual capital, firms' market value and financial performance', Journal of Intellectual Capital, Vol. 16, No. 3, pp.587-618.

Ongore, V.O. and Kusa, G.B. (2013) 'Determinants of financial performance of commercial banks in Kenya', International Journal of Economics and Financial Issues, Vol. 3, No. 1, pp.237-252.

Piao, S. (2010) 'The impacts of climate change on water resources and agriculture in China', Nature, Vol. 467, pp.43-51.

Poaponsakorn, N. and Meethom, P. (2013) Impact of the 2011 Floods, and Flood Management in Thailand, ERIA Discussion Paper Series No. ERIA-DP-2013-34.

Rachdi, H. (2013) 'What determines the profitability of banks during and before the international financial crisis? Evidence from Tunisia', International Journal of Economics, Finance and Management, Vol. 2, No. 4, pp.330-337.

Rahman, M.M., Hamid, M.K. and Khan, M.A. (2015) 'Determinants of bank profitability: empirical evidence from Bangladesh', International Journal of Business and Management, Vol. 10, No. 8, doi:10.5539/ijbm.v10n8p135.

Rosenzweig, C., Tubiello, F.N., Goldberg, R., Mills, E. and Bloomfield, J. (2002) 'Increased crop damage in the US from excess precipitation under climate change', Global Environmental Change, Vol. 12, No. 3, pp.197-202.

Roy, A. (2016) 'Corporate governance and firm performance: a study of Indian listed firms', Metamorphosis: A Journal of Management Research, Vol. 15, No. 1, pp.31-46.

Sami, H., Wang, J. and Zhou, H. (2011) 'Corporate governance and operating performance of Chinese listed firms', Journal of International Accounting, Auditing and Taxation, Vol. 20, No. 2, pp.106-114.

Siddik, M., Kabiraj, S. and Joghee, S. (2017) 'Impacts of capital structure on performance of banks in a developing economy: evidence from Bangladesh', International Journal of Financial Studies, Vol. 5, No. 2, p.13.

Sritharan, V. (2018) 'Firm size influence on profitability of Sri Lankan diversified holdings farms', International Journal of Advanced Research in Management and Social Sciences, Vol. 7, No. 6, pp.34-44.

Tobin, J. (1958) 'Liquidity preference as behavior towards risk', The Review of Economic Studies, Vol. 25, No. 2, p.65.

UNDP (2017) Enhancing Resilience to Extreme Climate Events: Lessons from the 2015-2016 El Niño Event in Asia and the Pacific, United Nations Development Programme (UNDP) Report, UNDP, New York, USA.

Upadhyay, A.D., Bhargava, R., Faircloth, S. and Zeng, H. (2017) 'Inside directors, risk aversion, and firm performance', Review of Financial Economics, Vol. 32, No. 1, pp.64-74.

Weng, P. and Chen, W. (2017) 'Doing good or choosing well? Corporate reputation, CEO reputation, and corporate financial performance', The North American Journal of Economics and Finance, Vol. 39, pp.223-240.

Wooldridge, J.M. (2006) Introductory Econometrics: a Modern Approach, South-Western Cengage Learning, Mason, Ohio.

Yu, M. (2013) 'State ownership and firm performance: empirical evidence from Chinese listed companies', China Journal of Accounting Research, Vol. 6, No. 2, pp.75-87.

Zouari, S.B.S. and Taktak, N.B. (2014) 'Ownership structure and financial performance in Islamic banks', International Journal of Islamic and Middle Eastern Finance and Management, Vol. 7, No. 2, pp.146-160. 